\title{
Swords into ploughshares? China's Soft Power strategy in Southeast Asia and its challenges ${ }^{1}$
}

\author{
De espadas a arados? A estratégia do Soft Power chinês \\ no Sudeste Asiático e seus desafios
}

http://dx.doi.org/10.1590/0034-7329201400203

TONY TAI-TING LIU*

TUNG-CHIEH TSA **

Rev. Bras. Polít. Int. 57 (special edition): 28-48 [2014]

\section{Soft Power and China's new diplomacy}

Aware of its rapid economic growth over the past three decades, China sees a peaceful and stable global environment as both a stabilizing force for continued economic development and an important precondition to joining the existing system (Hsu 2007, 51). Challenged by negative connotations of the "China threat" theory, ${ }^{2}$ China began its own peaceful retaliation by adopting a soft power strategy. The "harmonious worldview" and "good neighbor policy" are the latest Chinese creations towards the goal of peace. For Beijing, improving relations with its neighbors reduce threats to national security and contribute to a favorable environment for development.

Academic Joseph Nye (1990a) proposed the concept of soft power. Nye sought to convince observers that power in the new age should not be solely

1 This article is greatly revised from an earlier version prepared for presentation at the Association of Chinese Political Studies (ACPS) International Symposium and 24 $4^{\text {th }}$ Meeting, King's College London, United Kingdom, June 18, 2011.

* National Chung Hsing University, Taichung, Taiwan (stanggoftibia1984@yahoo.com.tw).

** National Chung Hsing University, Taichung, Taiwan (tctasi@dragon.nchu.edu.tw).

2 The China threat theory is first proposed in a policy report by the Heritage Foundation (1992) authored by Robert Ross. The report aimed to alert the US policy circle that as a result of a great value divide between China and the US, China's increasing capability may lead to an inevitable clash between the two powers. On the other hand, issues such as the attraction of investment capital, rising nationalism, neglect for environmental issues, organized crime, territorial and historical disputes are all concerns neighboring countries have against China. Japan, South Korea and Southeast Asian countries would continue to have reservations over China as an expansionist power. Herbert Yee and Ian Storey provide a comprehensive account of the China threat. See: Herbert Yee and Ian Storey eds., The China Threat: Perception, Myths and Reality (New York: Routledge, 2002). 
focused on military strength and domination; technology, education and economic development are all important aspects of power (Nye 1990b, 179). These new sources are all categorized under the rubric "soft power" (Nye 1990b, 181-182). Soft power denotes changes to the meaning of power in the post-Cold War period.

Specifically, hard power refers to the direct command power over tangible resources while soft power refers to the indirect or co-optive power to influence others (Nye 1990c, 31). Hard power forces others to do things they do not want to do through the use of rewards or threats; soft power induces others to voluntarily pursue the wishes of the powerful through the use of attraction (Keohane and Nye $1998,86)$. Together, both kinds of power encompass influences that range from coercion to attraction and rely on influencing other's behavior to achieve one's self interest (Nye 2002, 9-10, 176).

Hard power uses inducements and threats, or carrot and stick, to directly force others to change their mentality or behavior; soft power induces others to voluntarily adopt rules of the system through an appeal to attractive concepts and ideas (Nye 2004, 7-8). Hard power and soft power are distinguished by the nature of the behaviors and resources applied. Command power refers to the ability to change other's behavior through threat or inducement. Co-optive power refers to the ability to shape other's expectations through the attraction of culture and values or the ability to influence political agenda (see Table 1).

Table 1. The meaning of power.

\begin{tabular}{|c|c|c|c|c|}
\hline & \multicolumn{2}{|l|}{ Hard } & \multicolumn{2}{|r|}{ Soft } \\
\hline $\begin{array}{l}\text { Spectrum } \\
\text { of behaviors }\end{array}$ & Command $\longleftarrow$ & Inducement & Agenda setting & $\stackrel{\text { Attraction }}{\longrightarrow}$ Co-opt \\
\hline $\begin{array}{l}\text { Most likely } \\
\text { resources }\end{array}$ & $\begin{array}{c}\text { Force } \\
\text { sanctions }\end{array}$ & $\begin{array}{l}\text { Payment } \\
\text { bribes }\end{array}$ & Institutions & $\begin{array}{l}\text { Values, culture, } \\
\text { policies }\end{array}$ \\
\hline
\end{tabular}

Source: Nye $(2004,8)$.

Further expanding on the theme of power, Nye divides power into three categories: military, economic and soft power (see Table 2). According to Nye's definition, the power to assimilate comes from culture, ideology and international institutions. Economic development and transnational corporate performance can be seen as sources of assimilation power as well (De Castro 2007, 81). An abundant number of reports consider economic relations as a measure of soft power. For example, the US and China's respective economic relationship with ASEAN and economic assistance towards Southeast Asia are often cited as empirical evidence of growing competition between the two powers in the region (US Senate Committee on Foreign Relations 2008; Lum, Morrison, and Vaughn 2008). 
Table 2. Three types of power.

\begin{tabular}{|l|l|l|l|}
\hline & \multicolumn{1}{|c|}{ Behaviors } & Primary Currencies & \multicolumn{1}{|c|}{ Government Policies } \\
\hline Military Power & $\begin{array}{l}\text { Coercion } \\
\text { Deterrence } \\
\text { Protection }\end{array}$ & $\begin{array}{l}\text { Threats } \\
\text { Force }\end{array}$ & $\begin{array}{l}\text { Coercive Diplomacy } \\
\text { War } \\
\text { Alliance }\end{array}$ \\
\hline Economic Power & $\begin{array}{l}\text { Inducement } \\
\text { Coercion }\end{array}$ & $\begin{array}{l}\text { Payments } \\
\text { Sanctions }\end{array}$ & Aid, Bribes, Sanctions \\
\hline Soft Power & $\begin{array}{l}\text { Attraction } \\
\text { Agenda Setting }\end{array}$ & $\begin{array}{l}\text { Values, Culture } \\
\text { Policies, Institutions }\end{array}$ & $\begin{array}{l}\text { Public Diplomacy } \\
\text { Bilateral and Multilateral } \\
\text { Diplomacy }\end{array}$ \\
\hline
\end{tabular}

Source: Nye $(2004,31)$.

Accordingly, the use of soft power became an important aspect of China's foreign strategy. A soft power strategy not only helped Beijing to dispel the global anxiety over the China threat theory but also promoted the image of Beijing as a guardian of international peace. In short, China's increased influence in soft power should be noted alongside the country's growing military and economic capability. ${ }^{3}$

A growing number of western scholars have taken heed of Beijing's continuing expansion in soft power (Huang and Ding 2006, 23). Joshua Kurlantzick (2007) explained in detail how China has demonstrated global influence through a soft power strategy. Joseph Nye (2005) among others also observed the trend of China's growing soft power vis-à-vis America's decline in soft power. Nye concluded that Washington should reflect on the fast closing gap in soft power between the two countries rather than focusing on the search for a containment strategy against China.

Regarding China's new strategy, no observer put it into the current international context better than David Shambaugh. As Shambaugh notes:

Engagement with ASEAN reflects an increased appreciation by China of the importance of norms and "soft power" in foreign policy. Chinese print media, television, music, food and popular culture are disseminating across Asia at an unprecedented level. China's growing appreciation of soft power is also evident in its efforts to popularize Chinese culture throughout the region. At the same time, China also makes an effort to train future generations of intellectuals, technicians and political elites around the world in its universities and technical

3 Regarding China rise, see: Chang-Yen Tsai and Hong-Yi Lien, "zhongguo jueqi dui zhongmei yu zhonge guanxi fazhan zhi zhanlue yihan" (The "Rise of China" and its Strategic Significance for the Development of China-US and China-Russia Relations), Prospect Quarterly, Vol.9, No.3 (2008), pp.81-128; Lang Kao, "ruhe lijie zhongguo jueqi" (How to Perceive the Rise of China?), Prospect Quarterly, Vol.7, No.2 (2006), pp.53-94; Chung-Cheng Chen and Hsin-Wei Tang, "zhongguo dalu jueqi dui dangqian guoji tixi de chongii" (The Trend of Current International System: A Rising Chinas Impact), Prospect Quarterly, Vol.6, No.4 (2005), pp.101-137. 
schools. China increasingly sees higher education as an instrument of foreign policy (Shambaugh 2004/2005, 77-78).

This article examines China's foreign policy in Southeast Asia from the perspective of soft power. The authors look into the guiding principles of China's soft power strategy—harmonious worldview and good neighbor policy—and examine Beijing's new diplomacy in Southeast Asia. Three aspects of China's soft power strategy are examined: cultural appeal economic relations and the ability to shape international institutions and political agenda.

\section{China's charm offensive in East Asia}

Realists suspicious of China's intentions behind its increasing comprehensive capability often point out the transition of power in the international system and how China might replace the US as the next global hegemon. If China's growth continues without disruptions, America's status as the world's largest economy may well be displaced within the coming decade. Fear of the China threat is captured in works such as The Coming Conflict with America, which touts Beijing as Washington's biggest challenger in the future (Bernstein and Munro 1997a; 1997b). In terms of Southeast Asia, the US Council of Foreign Relations claimed that China is the source of serious economic, military and political challenges for the US and Southeast Asia (Kerrey and Manning 2001, 17). Global Trends 2015 , a report by the National Intelligence Council $(2000,63)$ also suggested that China's rise might cause significant uncertainties in regional affairs, especially in Southeast Asia.

For China, the adoption of a soft power strategy in foreign policy was an essential move to cast away doubts surrounding its rise. A soft power strategy achieves two important goals for China: (1) reduce the impact of the China threat theory and its challenges on national security, and (2) improve China's relations with neighboring countries. China's soft power strategy is guided by the harmonious worldview and good neighbor policy, concepts that contribute to the strategic and tactical levels of policy respectively. We discuss the concepts in turn.

\section{Slogan revised: proposal of the harmonious worldview}

In 2003, China proposed the catch phrase "peaceful rise" and made an open attempt at association itself with peace. However, to the surprise of the Chinese Communist Party (CCP), the proposal backfired and generated negative impressions on China instead. It is not difficult to understand why: "rise" implies a growth in relative power, possible transformations to the status quo and potential threat towards other countries. Under the realist assumption that a state pursues its own interests and security under anarchy, another state's increase in power 
essentially means a challenge to the status quo. The inevitable result is insecurity and the rise of a security dilemma (Waltz 1979). Any state that seeks to increase its security has the unintended effect of decreasing the security of others (Jervis 1998, 317). When a state pursues power and security, a security dilemma results, as another state's pursuit of security is challenged (Buzan 1991, 295). Concerns with the term "rise" caused China to slowly give up the phrase "peaceful rise" and propose the new concept of "harmonious world." (Chao and Hsu 2009, 4-8).

The term "harmonious world" first appeared in the 2005 Asia-Africa Summit in Jakarta. In the summit, China's President, $\mathrm{Hu}$ Jintao, pointed out that countries from Asia and Africa should jointly "promote friendship, equal dialogue, prosperity among civilizations and jointly establish a harmonious world.” (Xinhua 2005). In the foreign ministers meeting of Asia-Europe Meeting (ASEM), then Chinese foreign minister Li Zhaoxing continued to stress that states should continue to strengthen cultural exchange, promote equal dialogue, accommodate each other, develop prosperity and jointly construct a harmonious world (PRC Ministry of Foreign Affairs). Promotion of the harmonious world was capped off by Hu's re-mentioning of the concept at the United Nations $60^{\text {th }}$ anniversary summit in the same year (Xinhua 2006). With China's top elites leading the way, Chinese officials and academics have since pronounced the concept on different occasions.

As China's new guiding concept in policy thinking, $\mathrm{Hu}$ Jintao made the following explanations regarding the harmonious worldview. First, China would maintain the spirit of multilateralism and realize common security. States around the world should join hands to deal with global security threats and abandon Cold War thinking. A new security concept founded on mutual trust, mutual prosperity and mutual cooperation should be established, as well as an equal and effective collective security mechanism that would contribute to international peace and security. Second, China would strive for mutual benefit and cooperation and realize common prosperity. China supports the establishment of a multilateral trade system that is complete, open, equal and non-discriminatory. In addition, China supports further improvement of the international system and would do its best to contribute to the joint development of nations. Third, China would maintain the spirit of accommodation and jointly construct a harmonious world. Based on the spirit of equality and openness towards diversity, China supports the diminishment of mutual suspicion and separation, the facilitation of democracy and the establishment of a harmonious world that accommodates different civilizations (Xinhua 2006).

Three aspects make up the realization of a harmonious world:

1) Active and voluntary multilateral diplomacy: Since the 1990s, China has hoped to expand its maneuvering space on the international stage through active participation in multilateral institutions. As of 2008, China is member to more than 130 international organizations and 
has signed more than 250 multilateral treaties (Tsai 2008, 28). China's participation in intergovernmental organizations and non-governmental organizations ranked 27 and 31 respectively among all nations, accounting for $61.19 \%$ and $58.14 \% .{ }^{4}$ By increasing China's participation in world affairs, multilateral diplomacy generates a positive image of China and increases the influence of Beijing (Medeiros and Fravel 2003, 22-24; Men 2007, 41).

2) Promotion of a harmonious environment: Extending from the "befriend thy neighbor" proposal in the $16^{\text {th }}$ CCP National Congress, Chinese premier Wen Jiabao further proposed the "three neighbor" (sanlin) policy of "be harmonious, pacify and enrich thy neighbor."

3) Emphasis on cultural exchange: For China, culture has become an important channel for promoting the harmonious worldview. China's fourth generation leadership used cultural identity to strengthen the belief of a harmonious world and cultural diplomacy to advance its foreign policy objectives. The establishment of Confucius Institutes and promotion of the Chinese language are notable examples of Beijing's emphasis on cultural exchange.

\section{Dual Strategy: The Promotion of Good Neighbor Policy}

The end of the Cold War ushered in the development of multiple poles in both global and regional affairs. As a result, great power relations not only underwent deep adjustments, economic globalization and interdependence among states also changed the working of international relations. In contrast to traditional security concerns such as geopolitics, military power and ideology, economics now plays an active role that cannot be neglected. China's economic security and future global strategy depends on whether the country can enter the international community peacefully.

China must expend efforts to ensure regional order as a foundation for sustainable economic development, as its short term national interest is contingent on stability in the Asia-Pacific region. Accordingly, China tried to foster cooperation and more equal relations with its neighbors. In addition, China invested great efforts towards improving its relations with Asian countries by establishing a regional system founded on the principle of mutual interest. The essence of China's good neighbor policy includes the following points:

1) Resolution of border conflicts through peaceful negotiations: The resolution of territorial disputes is an important aspect and goal of China's good neighbor policy.

4 "geguo canyu guoji zuzhi de bijiao" (Comparison of State Participation in International Organisations), available at <http://big5.china.com.cn/node_7000058/2007-04/02/content_8047488.htm>. 
2) Establishment of cooperative relations and bilateral dialogue: Another important aspect of the good neighbor policy is the promotion of cooperation and exchange. The purpose of establishing partnerships is to advance bilateral relations and resolve potential conflicts.

3) Participation in multilateralism and joint conflict resolution: Perhaps due to an increase in confidence that accompanied rapid economic growth, China moved from suspicion to acceptance of multilateralism. China has moved away from isolation and turned towards more active participation in multilateral security dialogues such as the ASEAN Regional Forum (ARF), the Shanghai Cooperation Organization (SCO) and the Boao Forum for Asia (Fukushima 2002, 183; Johnston and Evans 1999).

4) Establishment of deeper economic cooperation: The establishment of deeper economic cooperation or consolidation of economic interactions with neighboring countries is an important aspect of China's policy. China promotes economic exchange through bilateral dialogues and multilateral talks at the same time.

Good neighbor policy is an effective reflection of China's harmonious worldview and basic strategic intentions. In 1997, the Chinese leadership iterated relevant policies more clearly at the $15^{\text {th }}$ Party Congress of the CCP (Chao and Hsu 2009 , 9). As China's President Jiang Zemin expounded, "affirming to a policy of good neighborliness has been the stance of this country for a long time and it will not change... regarding issues of conflict between China and its neighbors, we should make an effort towards maintaining peace, stabilizing the overall situation and seeking resolution through friendly negotiations. If the issue cannot be resolved at once, it will be temporarily put aside... search for common ground and save the differences."

The working report of the $16^{\text {th }}$ Party Congress also points out that "(China) must continue to affirm to the principles of good relations and companionship, regional cooperation and consolidation of exchange and cooperation with neighboring countries." The report is also significant in that it was the first time the phrase yilinweiban, yilin weishan, or literally "befriending and maintaining good relations with thy neighbor," is mentioned, deepening the meaning of good neighbor policy. Finally, in the $17^{\text {th }}$ Party Congress of the CCP, China's President $\mathrm{Hu}$ Jintao re-emphasized China's determination on realizing good neighborliness.

\section{Uncertain friendship: reviewing China-ASEAN relations}

A retrospect of China-ASEAN relations after the Cold War is critical for understanding China's policy in Southeast Asia and its potential development in the near future. From the standpoint of China, relations with ASEAN can be divided into the following periods. 


\section{Period of cautious participation (1991-1996)}

In this period, China's interest towards the establishment of multilateral security forums in the region was limited, as Beijing was anxious over potential territorial challenges that may arise through multilateral institutions. Despite China's participation in the ASEAN foreign ministers meeting in 1991, the ARF in 1994 and the ASEAN-SOM on political security in 1995, Beijing continued to be concerned over the possible tradeoff between deeper interaction and national interest (Cheng 2008, 105-106).

A semi-official report released by the Chinese Academy of Social Science (CASS) points out that in spite of the above concerns, ${ }^{5}$ China decided to participate in the ARF after careful calculations. In the same report, China is encouraged to adopt pragmatism in order to participate in the irrevocable trend of multilateral security cooperation in the Asia Pacific. CASS emphasized that China must take more active initiative in shaping regional institutions in order to secure a favorable position amidst a fast changing and complicated environment. For China, choosing to do nothing was not an option, as it would only become isolated and encourage concerns from ASEAN and others (Chinese Academy of Social Science Institute of Asia-Pacific Studies 1994, 16). Nonetheless, wariness towards multilateralism did not keep China outside of regional institutions for too long (Cheng 2008, 108). In 1996, ASEAN accepted China as a full dialogue partner and opened a new page in bilateral relations.

\section{Period of active participation (1997-2000)}

After a few years of initial alarm, China's attitude towards multilateralism changed. Beijing came to accept the fact that multilateral forums do not necessarily challenge national security. In contrast, forums and other regional institutions could serve as channels for the promotion of China's foreign policy agenda. Although China focused more on bilateral diplomacy in this period, multilateral diplomacy gradually played a stronger complementary role (Cheng 2008, 107), especially after the Asian Financial Crisis.

Two factors caused China to change its perception of ASEAN and multilateralism. First, as the ARF is founded on the "ASEAN way" or principles including consultation, consensus, incremental progress and unofficial nature, China could participate without too much concern (Foot 1998, 428). Second,

5 China had several concerns regarding participation in the ASEAN Regional Forum. First, Beijing feared that the forum may be dominated by Washington and used by the US to intervene in the domestic affairs of other states. Second, Beijing was worried that ASEAN may use the forum to internationalize the South China Sea issue. Third, Beijing was worried that the Taiwan issue may be discussed in the forum. Fourth, Beijing was concerned over the issue of military transparency. These concerns caused Beijing to think that the ARF may limit its power and restrict its strategic choices. 
ASEAN's unique role of balancing relations among great powers while maintaining its leadership in the ARF reduced China's worries. The factors dissuaded Beijing from holding on to the thought of possible development of the ARF into an anti-China alliance. On the other hand, China entered into various confidence building measures (CBM) in order to dismiss the conception of a China threat (Cheng 2008, 42). China also emphasized the "new security concept" through the $\mathrm{ARF}$ and other multilateral institutions in hopes of shaping a favorable security environment in the Asia Pacific (Capie and Evans 2002, 175).

Period of voluntary initiative (2001-2008)

China's support for regional multilateralism reached a high point in the new century. In 2001, China and ASEAN agreed to establish a free trade area (FTA) within a decade; in 2002, China and ASEAN signed the Framework Agreement on Comprehensive Economic Cooperation. Establishment of the ACFTA demonstrates China's change towards taking initiative in making regional proposals, a major transformation from its earlier stance of receiving and responding to suggestions from others. For China, multilateral forum became an important channel to short-term policy into long-term strategy. China's perception and policy towards multilateral institutions clearly moved from caution and suspicion to action and optimism.

In the new century, China turned to more multilateral policy and actively promoted regional dialogue. The basic guiding principle of China's foreign policy in the new century was to develop stable security relations with neighboring states; an important aspect of China's core interest (hexin liyi) is the establishment of a peaceful and stable regional environment. In the words of China's National Defense White Paper, "China longs for an environment of long term peace, especially an environment favorable for development" (Bert 2003, 112). In short, China's relations with Southeast Asia greatly improved in this period as a result of Beijing's active participation in bilateral and multilateral agreements and institutions (Sutter $2008,261)$.

\section{Period of competing leadership (2009-)}

Since the turnover of administration in the US in 2008, US foreign policy towards Southeast Asia took a turn as well. After entering office, US President Barack Obama expressed Washington's will to return to Southeast Asia and seek the reinforcement of bilateral relations with states in the region. As Asia Pacific economies took off in the new century, the US focused on returning to Asia (Hsiung 2011).

For China, Washington's return to Asia entails many economic and security implications. The US led Transpacific Partnership (TPP) initiative poses challenges 
against China's effort to consolidate its leadership role in East Asia. The TPP contests the growing prominence of the ACFTA by bringing the leadership question in East Asia to the forefront of debates once again (Hung and Liu 2012). As a plan that essentially extends the concept of APEC, the TPP places the US at the heart of regional integration, a move that corresponds well with Washington's "return to Asia" policy. Besides the potential economic consequences of the TPP, the US led partnership agreement also has the effect of strengthening Washington's relationship with its allies in Southeast Asia, extending the traditional US huband-spoke strategy in the region.

In terms of security challenges, US presence in the ARF and the South China Sea issue significantly altered the balance of power in Southeast Asia. China's economic rise over the past decade has translated into the country's growing dominance in discourse over geopolitics and regional security. The implication of China's growing power is that Beijing has become more assertive on territorial issues such as the South China Sea (Hung and Liu 2011, 112). US reconsolidation of its status in the region and its open proclamation to serve as a neutral third party in the South China Sea dispute generated a key variable in regional security that was unforeseen by China. US reinforcement of its position in Southeast Asia has given countries in the region the opportunity to hedge and balance between China and US, a strategy that may significantly undermine the support China has been trying to gather since the Asian financial crisis (Liu 2011).

In short, since America's return to Asia, the bipolar power structure shared between China and the US has become ever more vivid in Southeast Asia. Sino-US competition in economics, geopolitics and various other aspects is fast becoming the overarching framework that dominates relations in Southeast Asia.

\section{Dissecting China's policy in Southeast Asia}

As mentioned above, China's determination to maintain the rate of the Renminbi (RMB) during the Asian financial crisis did not only improve economic stability in Southeast Asia, the move also increased China's influence in the region and commenced a new period in bilateral relations (Lum, Morrison and Vaughn 2008, 2). On the other hand, the Declaration on the Conduct of Parties in the South China Sea signed between China and ASEAN hints at Beijing's shift in strategy towards soft power (Lum, Morrison and Vaughn 2008). In 2003, China renewed its commitment to the non-aggression treaty signed with ASEAN in 1976 and the Treaty of Amity and Cooperation in Southeast Asia, which forbids participating member states from resorting to violent means in resolving issues. In the same year, China and ASEAN issued the Joint Declaration on Strategic Partnership for Peace and Prosperity.

Hitherto, the Asian financial crisis is deemed as an important turning point in China-ASEAN relations. At least before 2009, states in Southeast Asia gradually 
leaned towards China and moved away from the US as a result of effective soft power from Beijing (Chew 2004; Garrison 2005, 26; Goldstein 2001, 845). Regardless of whether we could consider the harmonious worldview and good neighbor policy as successful examples of China's soft power, it is clear that Beijing is putting its soft influence to work. This section examines China's application of soft power in four aspects: (1) the promotion of cultural ideology and values; (2) the formation of international rules and agenda setting; and (3) economic exchange and interaction.

\section{From Beijing Consensus to Confucius Institute}

In an article that criticized the US and brought attention to China's increasing political influence, Zhang Weiwei (2006) argued that the so-called Washington Consensus is largely driven by ideology and with little regard for local conditions. Zhang pointed out that the US treated sub-Saharan Africa and other less developed regions as developed societies where western institutions could be implemented and automatically take root. The US should be accountable for imposing market liberalization before safety nets were set up; privatization before regulatory frameworks were put in place; and democratization before a culture of political tolerance and rule of law was established. As Zhang (2006) concludes, "the end result has often been discouraging or even devastating."

On the other hand, Joshua Cooper Ramo $(2004,3)$ introduced the concept of Beijing Consensus and described the impact of the China model on economic, social and political developments around the world. The Beijing Consensus began to chip away at the influence of the Washington Consensus in light of the Bush administration's lean towards unilateralism in foreign policy. The Chinese model encourages developing states to protect their own lifestyle and political choice. Even though developing states could not completely copy China's development path, the China model provides a new way for thinking about development and an alternative to the Washington Consensus (Men 2007, 38). Particularly in developing states, the Beijing Consensus seems to be more popular than the US led Washington Consensus due to the implication that leaders from authoritarian states could maintain a firm grasp on power while pursuing economic development at the same time (Cho and Jeong 2008, 466; Sutter 2006, 54; 2008, 95). A number of states have come to accept China's idea of "reducing poverty and securing the right to survival as the highest respect for human right," a response to US democracy and economic development (Tsai 2008, 186-187).

Through the China model or the Beijing Consensus, China gained much soft power in ideological and cultural values. Accordingly, China demonstrated its

6 Zhang points out that Haiti, Philippine and Iraq are all failed examples of the American model. 
influence by causing Southeast Asian countries to voluntarily imitate and accept rules of the Chinese system. On the other hand, China successfully encouraged Southeast Asia to accept its preferences. Both aspects were beneficial for China's efforts to promote multilateral institutions and its own political agenda. The China model not only served as a development model for Southeast Asia, the model also proved helpful in later multilateral establishments such as the ACFTA.

Furthermore, the rise of China has encouraged the study of Chinese history, culture and language worldwide. There are signs that Beijing has caught on to the phenomenon and begun to use the "China fever" (zhongguore) to improve its outer image. An often cited example of China's increasing popularity is the establishment of the Confucius Institute. However, the promotion of Chinese culture is not merely a passive result of a global development, it is also an important part of China's public diplomacy (Kurlantzick 2007, 69-70). In terms of actual policy, China established the Office of Chinese Language Council (Hanban) in 1987 and commenced the first Confucius Institute in 2004 (Ding and Saunders 2006, 19). The Confucius Institute is headquartered in Beijing and over the past decade, China has actively promoted the establishment of branch institutes around the world. The main framework guiding China's establishment of Confucius Institutes is the "Chinese Bridge Project," which emphasizes both the establishment of Confucius Institutes and the development of multimedia resources for teaching and learning (Ding 2006, 19-20). Currently, there are 896 institutes established across 108 countries and regions (as of August 2012). Forty-one institutes are located in Southeast Asia (see Table 3). ${ }^{7}$

7 "Kongzixueyuan: zhongguo wenhua yongbao shijie" (2011 Confucius Institute Asia Conference held in Korea), available at <http://cpc.people.com.cn/BIG5/n/2012/0810/c83083-18711779.html>, accessed on August 10, 2012. 
Table 3. Confucius Institutes in Southeast Asia.

\begin{tabular}{|c|c|}
\hline Thailand & $\begin{array}{l}\text { Confucius Institute at Kasetsart University } \\
\text { Confucius Institute of Betong Municipality } \\
\text { Confucius Institute at Chulalongkorn University } \\
\text { Confucius Institute at Bansomdejchaopraya Rajabhat University } \\
\text { Confucius Institute at Khon Kaen University } \\
\text { Confucius Institute at Chiang Mai University } \\
\text { Confucius Institute of Suan Dusit Rajabhat University at Suphanburi } \\
\text { Confucius Institute at Prince of Songkla University } \\
\text { Confucius Institute at Phuket, Prince of Songkla University } \\
\text { Confucius Institute at Burapha University } \\
\text { Confucius Institute at Mahasarakham University } \\
\text { Confucius Institute at Mae Fah Luang University } \\
\text { Confucius Classroom at Lampang Kanlayanee school } \\
\text { Confucius Classroom at Rayong Wittayakorm School } \\
\text { Confucius Classroom at Suankularb Wittayalai School } \\
\text { Confucius Classroom at Nawamintachinuthia School } \\
\text { Confucius Classroom at Assumption Commercial School } \\
\text { Confucius Classroom at Swang Boriboon Witaya School } \\
\text { Confucius Classroom at Srinakorn Middle School } \\
\text { Confucius Classroom at Xingmin School Phitsanulok } \\
\text { Confucius Classroom at Phuket Wittayalai School } \\
\text { Confucius Classroom at Chltralada School } \\
\text { Confucius Classroom at Traimit Wittayalai High school }\end{array}$ \\
\hline Singapore & $\begin{array}{l}\text { Confucius School in Singapore } \\
\text { Confucius Institute at the Nanyang Technological University }\end{array}$ \\
\hline Malaysia & $\begin{array}{l}\text { Kongzi Institute for the Teaching of Chinese Language at the University of Malaya } \\
\text { Shanghai Jiaotong University-Malaysia Global Hanyu \& Culture Center }\end{array}$ \\
\hline Philippine & $\begin{array}{l}\text { Confucius Institute at Angeles University Foundation } \\
\text { Confucius Institute at Bulacan State University } \\
\text { Confucius Institute at Ateneo de Manila University }\end{array}$ \\
\hline Indonesia & $\begin{array}{l}\text { Pusat Bahasa Mandarin at Universitas Negeri Surabaya } \\
\text { Pusat Bahasa Mandarin at Hasanuddin University } \\
\text { Pusat Bahasa Mandarin at Malang State University } \\
\text { Pusat Bahasa Mandarin at Tanjungpura University } \\
\text { Pusat Bahasa Mandarin at Maranatha Christian University } \\
\text { Pusat Bahasa Mandarin at University of Al Azhar Indonesia } \\
\text { Kongzi Institute at the Mandarin Education Center of Jakarta }\end{array}$ \\
\hline Myanmar & $\begin{array}{l}\text { Confucius Classroom at Fuxing Language and Chinese Class } \\
\text { Confucius Classroom at Fuqing Language and Computer School }\end{array}$ \\
\hline Laos & Confucius Institute at National University of Laos \\
\hline Cambodia & Confucius Institute of Royal Academy of Cambodia \\
\hline
\end{tabular}

Source: Confucius Institute Online, available at <http://college.chinese.cn/en/node_3757.htm>. 
The Confucius Institute is a concrete example of Chinese soft power in Southeast Asia. These institutes are not only culturally attractive sites that serve as a response to the China fever, they also function as sites that export Chinese culture and language abroad. The Confucius Institutes increased China's influence in Southeast Asia through the promotion of language, tradition and culture. In addition, the Confucius Institutes also helped to shape a benevolent image of China, an example of political spillover from a cultural exchange and education policy (Halloran 2007, 54-55). Through a soft power strategy, China strengthened its relations with Southeast Asia, achieved the goal of establishing a "peaceful and favorable environment for development" and successfully protruded China's benign image on the world stage. As French (2006) pointed out, Beijing is determined to expand its influence while gaining the favor of other countries. By choosing the name "Confucius Institute," China hoped to mitigate the generally negative impression of the CCP and its connection with party ideology and to reduce concerns among Southeast Asian countries of a rapidly rising neighbor (French 2006).

\section{Consolidating cooperation through agenda setting}

Since declaring its intent to play the role of "a responsible power in the international community," China's capacity for handling international responsibility seemed to have increased. Beijing came to realize that participating in international institutions is critical in breaking out of isolation and achieving the reputation of a responsible power (Men 2007, 40-41). After the Asian financial crisis, China not only changed the impression of Southeast Asian countries, China became an active participant of regional institutions as well. The ASEAN plus meetings, ASEAN Regional Forum, East Asia Summit (EAS) and the Greater Mekong Sub-region (GMS) project are some of the more notable multilateral forums China has entered into. In addition, from the establishment of the ACFTA, we can observe China's capacity to set rules and agendas.

In terms of the ACFTA, Chinese Premier Zhu Rongji stated at the Fourth ASEAN plus 3 Summit in 2000 that China would like to expand its global influence by joining ASEAN. In the 2001 summit, Zhu's call was heeded, as China and ASEAN agreed to the establishment of FTA within a decade. In 2002, the signing of a bilateral framework agreement officially put the ACFTA in motion. China and ASEAN subsequently signed the Treaty of Amity and Cooperation in Southeast Asia, the Joint Declaration on Strategic Partnership for Peace and Prosperity, the Agreement on Trade in Goods of the Framework Agreement on Comprehensive Economic Co-Operation and the Agreement on Dispute Settlement Mechanism of the Framework Agreement on Comprehensive Economic Co-Operation. With a population of 1.9 billion people and a total sum of production of US\$ 6 trillion, 
which trails only the European Union and NAFTA in terms of economic scale, realization of ACFTA abolished all tariffs between China and Southeast Asia and formalized cooperation in various areas between the two parties.

Despite US effort to re-balance China through its alliances in the EAS, US influence in East Asia declined in recent years (Lum, Morrison and Vaughn 2008, 4). On the other hand, China's influence continued to grow with its economic development. The contrast between China and US influence reveals an opportunity for China. Through the use of soft power, particularly in terms of rule-making and agenda setting, China has the chance to gradually push out US influence from Southeast Asia while reducing the security concern of neighboring states. For ASEAN, not only could China's rise be beneficial for its economic development, the participation of China in regional affairs could also increase the status of Southeast Asia. In addition, China's presence in ASEAN provides Southeast Asian countries a balance against US influence and increased bargaining power on the world stage.

\section{Economic exchange: a double-edge knife}

Perhaps a result of Beijing's good neighbor policy in recent years, bilateral and multilateral cooperation between China and ASEAN clearly advanced in the post-Cold War period. Economics was a key driving force behind the advancement in bilateral relations. For China, Southeast Asia provides three benefits: natural resources for industrial development, a market that could help digest China's excess production and a large inflow of foreign direct investment. The three factors have led to the blossoming of trade between China and Southeast Asia, which expanded from US\$ 25 billion in 1997 to US\$ 231 billion in 2008 (Lum, Morrison, and Vaughn 2008, 11; Storey 2007, 7). Regarding the development of economic relations between China and ASEAN, as ASEAN Secretary Ong Keng Yong puts,

ASEAN sees China as a close neighbor and an important dialogue partner that is surprisingly helpful. With its rapid economic growth and huge population, China can become an important consumer of ASEAN products. At the same time, China can also become a great source of foreign direct investment for ASEAN. In addition, the ASEAN economy can benefit from the large volume of visiting Chinese tourists (ASEAN).

Figures and data support the claim of growing economic relations between China and ASEAN. From 1997 to 2011, China's total export to ASEAN countries grew $1239.45 \%$ while total import from ASEAN grew 1460.01\%. China's export to ASEAN increased from US\$ 12.7 billion in 1997 to US\$ 170.1 billion in 2011 while import from ASEAN increased from US\$12.4 billion to US\$1,592.8 billion in the same period. In terms of trade and investment, China plays an important economic role for ASEAN. The ACFTA and other agreements can be expected to further tighten relations between China and ASEAN (see Table 4). 
Table 4. Trade between China and ASEAN (in US\$ millions).

\begin{tabular}{|l|l|l|l|l|l|l|l|l|l|}
\hline & 1997 & 2005 & 2006 & 2007 & 2008 & 2009 & 2010 & 2011 & $\begin{array}{l}\text { 2010-2011 } \\
\text { (\% change) }\end{array}$ \\
\hline
\end{tabular}

Source: <http://yzs.mofcom.gov.cn/aarticle/g/date/p/201202/20120207946820.html>.

Regarding foreign investment, from 2009 to 2011 alone, China's total investment in Southeast Asia amounted to US\$ 13.01 billion. Until June 2012, China's investment in Southeast Asia reached US\$ 188 billion and covered sectors that ranged from construction, recreation and transportation to electricity and natural resources. In terms of economic assistance, China is currently the biggest donor of foreign aid in Southeast Asia. Chinese aid in Southeast Asia grew significantly in the past decade and now rivals Japanese aid in the region. China not only provides aid to small states that are strategically important such as Myanmar, Laos and Cambodia, it also provides a great amount of aid to more developed states such as Thailand, Indonesia and Philippine (Lum, Morrison and Vaughn 2008, 3-7).

In short, it is clear that China plays a very important role in terms of ASEAN's economic relations. However, regardless of China's growing economic influence, whether Beijing could really transform its economic prowess into soft influence in Southeast Asia remains an open ended question. After all, as China becomes a towering economic giant, it may become a powerful competitor for ASEAN and not just a benevolent sponsor.

\section{Conclusion: an indefinite future}

In response to the China threat theory, China promoted the harmonious worldview and good neighbor policy. For China, improving relations with Southeast Asia not only reduces threats to national security but also contributes to the establishment of a stable and peaceful international environment favorable for economic development. In a certain sense, China and ASEAN share the common interest of peace and development. The approach used to realize the concepts—soft power-is therefore an important aspect in China's foreign policy worthy of attention.

After economic reform in 1978, China emerged onto the international stage. The impact of China rising in recent years is widespread fever around the world over Chinese culture, history and language. Beijing recognized the global appeal of China and moved forward to improve its image by using a soft power strategy 
to promote the cultural fever over China. Yet a series of questions remain: how long would the current wave of China fever last? Can the fever be sustained? Can Chinese culture gain as much appeal as US popular culture and penetrate the world? Can Chinese or Hanyu replace English and become the new world language? Can Beijing acquire real soft power through the current fever? These questions remain debatable. In the meantime, China must continue to carry out its soft power policy in order to sustain its rise.

The increasing popularity of the Chinese model for development is testament to the claim that economic development does not necessarily have to go along with democracy. The China model offers an alternative route for economic development. Unlike the Washington Consensus, the Beijing Consensus digresses from the traditional approaches towards development and emphasizes the fact that all states should develop according to their own national characteristics. China's conception of development appeals to Southeast Asia and other developing regions that have suffered from conforming to the Washington Consensus. The Beijing Consensus has become a powerful rival of the Washington Consensus in recent years. However, similar to anxiety surrounding the China fever, questions remain as well for the Beijing Consensus. Is the Beijing Consensus workable outside China? Can it represent a "Chinese" way of development? Can the Beijing Consensus replace the existent appeal of the Washington Consensus? Can China increase its soft power through the Beijing Consensus? Only time has the answer to these questions.

Lastly, despite China's increasing influence in Southeast Asia and the wider region of East Asia, challenges lie ahead for China. First, as Nye (2010) points out, in terms of appeal, China's soft power trails behind the US, Europe and Japan. In other words, China still has room to improve on the content and attractiveness of its soft power. Second, despite China's rising soft power and its effect on changing Southeast Asia's view of Beijing, only naivety could lead one to conclude that anxiety over the China threat has dispelled. In fear of Southeast Asia's potential fall into Beijing's sphere of influence, many countries in the region continue to demonstrate ambivalence over China's rapid rise. In response, ASEAN continues to bring major powers into the region to balance China's challenge to regional order.

With the change of leadership in China in 2012 and China's slowing economy, it remains to be seen whether Beijing will continue to carry out a soft power strategy in Southeast Asia.

\section{Bibliographic references}

ASEAN. "ASEAN-China Relations: Harmony and Development." Availability: <http://www. aseansec.org/19031.htm>.

Berstein, Richard and Ross Munro. "China I: The Coming Conflict with America." Foreign Affairs 76, no. 2 (1997): 18-32.

Berstein, Richard and Ross Munro. The Coming Conflict with China. New York: Albert Knopf, 1997. 
Bert, Wayne. The United States, China and Southeast Asian Security: A Changing of the Guard? New York: Palgrave Macmillan, 2003.

Buzan, Barry. People, State and Fear: A Agenda for International Security Studies in the Post-Cold War Era. Boulder: Lynne Rienner, 1991.

Capie, David and Paul Evans. The Asia-Pacific Security Lexicon. Singapore: Institute of Southeast Asian Studies, 2002.

Chao, Chien-Min and Chih-Chia Hsu. "zhonggong disidai lingdao jiti de hexie shijieguan: lilun yu yihan (China's Harmonious World: Theory and Significance) Prospect Quarterly 10, no. 1 (2009): 1-44.

Chen Chung-Cheng and Hsin-Wei Tang. "zhongguo dalu jueqi dui dangqian guoji tixi de chongji" (The Trend of Current International System: A Rising China's Impact) Prospect Quarterly 6, no. 4 (2005): 101-137.

Cheng, Chwee Kuik. "Multilateralism in China’s ASEAN Policy: Its Evolution, Characteristics and Aspiration." Contemporary Southeast Asia 27, no. 1 (2008): 102-122.

Chew, Eric Teo Chu. "China's Rising Soft Power in Southeast Asia.” PacNet, no. 19a (May 3, 2004): 1-2.

Chinese Academy of Social Science, Institute of Asia Pacific Studies. "yatai xinshi fenxi 1994" (Analysis of the Asia Pacific 1994) Journal of Contemporary Asia-Pacific Studies, no. 1 (1994): 16.

Cho, Young Nam and Jong Ho Jeong. "China's Soft Power: Discussion, Resources and Prospects.” Asian Survey 48, no. 3 (2008): 453-472.

De Castro, Renato Cruz. "The Limits of Twenty-First Century Chinese Soft-Power Politics in Southeast Asia: The Case of the Philippines." Issues and Studies 43, no. 4 (2007): 77-116.

Ding, Sheng and Robert Sauders. "Taking Up China: An Analysis of China's Rising Cultural Power and Global Promotion of the Chinese Language.” East Asia: A International Quarterly 23, no. 2 (2006): 3-33.

Foot, Rosemary. "China in the ASEAN Regional Forum," Asian Survey 38, no. 5 (1998): 425-440.

French, Howard. "Another Chinese Export is All the Rage: China’s Language.” New York Times, January 11, 2006.

Fukushima, Akiko. "Multilateralism and Security Cooperation in China," in Benjamin Self and Jeffrey Thompson eds., An Alliance for Engagement: Building Cooperation in Security Relations with China. Washington DC: Stimson Center, 2002: 165-188.

Garrison, Jean. "China's Prudent Cultivation of 'Soft Power' and Implications for US Policy in East Asia." Asian Affairs: An American Review 32, no. 1 (2005): 25-30.

Goldstein, Avery. “The Diplomatic Face of China’s Grand Strategy: A Rising Power's Emerging Choice." The China Quarterly, no. 168 (2001): 835-864.

Halloran, Richard. "Going Soft: China's Alternative Route to Regional Influence." Jane's Intelligence Review 19, no. 7 (2007): 54-55.

Hsiung, James. "Jiedu Oubama Zoufang Dongya Ji Zhongguo Zhi Yongyi Yu Chengxiao" (Explaining Obama's Visit to East Asia and its Implications and Effects on China) Strait Review, no. 228 (2011). Availability: <http://www.haixiainfo.com.tw/SRM/2287749.html>. 
Hsu, Chih-Chia Hsu. "zhongguo xin mulin waijiao zhengce: zhanlue yihan yu zuowei" (China's New Good Neighbour Foreign Policy: Strategy and Behavior) Prospect Quarterly 8, no. 3 (2007): 43-90.

Huang, Yanghong and Sheng Ding. “The Dragon's Underbelly: An Analysis of China's Soft Power." East Asia: An International Quarterly 23, no. 4 (2006): 23-44.

Hung, Ming-Te and Tony Tai-Ting Liu. "Sino-US Strategic Competition in Southeast Asia: China's Rise and US Foreign Policy Transformation since 9/11.” Political Perspectives 5, no. 3 (2011): 96-119.

Hung, Ming-Te and Tony Tai-Ting Liu. "The Trans-Pacific Strategic and Economic Partnership and its Implications for China's Role in East Asia Regional Integration." Journal of Contemporary Eastern Asia 11, no. 2 (2012) (forthcoming).

Institute of Southeast Asian Studies. Developing ASEAN-China Relations: Realities and Prospects - A Brief Report on the ASEAN-China Forum. Singapore: Institute of Southeast Asian Studies, 2004.

Jervis, Robert. "Realism, Games Theory and Cooperation." World Politics 40, no. 3 (1998): 317-349.

Johnston, Alastair Iain and Paul Evans. "China’s Engagement with Multilateral Security Institutions," in Alastair Iain Johnston and Robert Ross eds., Engaging China: The Management of an Emerging Power. New York: Routledge, 1999: 241-278.

Kao, Lang. "ruhe lijie zhongguo jueqi" (How to Perceive the Rise of China?). Prospect Quarterly 7, no. 2 (2006): 53-94.

Keohane, Robert and Joseph Nye. "Power and Interdependence in the Information Age." Foreign Affairs 77, no. 5 (1998): 81-94.

Kerrey, J. Robert and Robert Manning. The United States and Southeast Asia: A Policy Agenda for the New Administration. New York: Council on Foreign Relations, 2001.

Kurlantzick, John. Charm Offensive: How China's Soft Power is Transforming the World. New Haven: Yale University Press, 2007.

Liu, Tony Tai-Ting. "Hedging and Balancing while Going the Third Way: ASEAN's Choices in East Asia Regional Integration.” Unpublished paper presented at the 2012 International Conference on Asia-Pacific Studies, National Sun-Yat Sen University, Kaohsiung, Taiwan, November 9-10, 2012.

Lum, Thomas, Wayne Morrison and Bruce Vaughn. China’s "Soft Power" in Southeast Asia, CRS Report for Congress RL34310.

Medeiros, Evan Medeiros and Taylor Fravel. "China's New Diplomacy." Foreign Affairs 82, no. 6 (2003): 22-35.

Men, Honghua. "zhongguo ruanshili pingu baogao (xia)" (Assessment Report on the Soft Power of China (Part 2)) International Review, no. 2 (2007): 15-26.

Ministry of Foreign Affairs, People's Republic of China. "li zhaoxin waizhang zai diqijie yaou waizhang huiyi shang de fayen" (Foreign Minister Li Zhaoxing's Statement at the Seventh ASEM Foreign Ministers Meeting). Availability: < http://www.mfa.gov.cn/chn//gxh/zlb/ldzyjh/ t195402.htm>, accessed July 5, 2011.

National Intelligence Council. Global Trend 2015: A Dialogue about the Future with Nongovernment Expert. Washington DC: US Government Printing Office, 2000. 
Nye, Joseph. "American and Chinese Power after the Financial Crisis." Washington Quarterly 33, no. 4 (2010): 143-153.

Nye, Joseph. "Soft Power." Foreign Policy, no. 80 (1990a): 153-171.

Nye, Joseph. "The Changing Nature of World Power." Political Science Quarterly 105, no. 2 (1990b): 177-192.

Nye, Joseph. “The Rise of China’s Soft Power.” Wall Street Journal, December 29, 2005.

Nye, Joseph. Bound to Lead: The Changing Nature of American Power. New York: Basic Books, 1990c.

Nye, Joseph. Soft Power: The Means to Success in World Politics. New York: Public Affairs, 2004.

Nye, Joseph. The Paradox of American Power: Why the World's Only Superpower Can't Go it Alone. New York: Oxford University Press, 2002.

Ramo, Joshua Cooper. The Beijing Consensus. London: Foreign Policy Center, 2004.

Shambaugh, David. “China Engages Asia: Reshaping the Regional Order.” International Security 29, no. 3 (2004/05): 64-99.

Storey, Ian. The United States and ASEAN-China Relations: All Quiet on the Southeast Asia Front. Carlisle Barracks: Strategic Studies Institute, 2007.

Sutter, Robert. "China's Rise, Southeast Asia and the United States," in Evelyn Goh and Sheldon Simon eds., China, the United States and Southeast Asia: Contending Perspectives on Politics, Security and Economics. New York: Routledge, 2008.

Sutter, Robert. China's Rise: Implications for US Leadership in Asia. Washington DC: East West Center, 2006.

Sutter, Robert. Chinese Foreign Relations: Power and Policy Since the Cold War. Maryland: Rowman and Littlefield, 2008).

Tsai, Chang-Yen Tsai and Hong-Yi Lien. "zhongguo jueqi dui zhongmei yu zhonge guanxi fazhan zhi zhanlue yihan" (The "Rise of China" and its Strategic Significance for the Development of China-US and China-Russia Relations) Prospect Quarterly 9, no. 3 (2008): 81-128.

Tsai, Tung-Chieh. Dangdai Zhongguo Waijiao Zhengce (China's New Diplomacy: Interpreting its Connotation and Tendency). Taipei: Wunan Book, 2008.

US Senate Committee on Foreign Relations. China's Foreign Policy and "Soft Power" in South America, Asia and Africa. Washington DC: US Senate Committee on Foreign Relations, 2008.

Waltz, Kenneth. Theory of International Politics. New York: McGraw Hill, 1979.

Williamson, John. A Short History of the Washington Consensus. Washington D.C.: Institute for International Economics, 2004.

Xinhua. "hu jintao zai yafeifenghui shang de jianghua quan wen" (Hu Jintao's Complete Speech at ASEM). Availability: < http://big5.xinhuanet.com/gate/big5/news.xinhuanet.com/ world/2005-04/22/content_286517>, accessed July 5, 2011.

Xinhua. "jianshe hexie shijie zhongguo waijiao sixiang de xin fazhan" (Building a Harmonious World: New Developments in China's Foreign Policy Thinking). Availability: <http://news. xinhuanet.com/world/2006-08/23/content_4993067.htm>, accessed July 8, 2011.

Yee, Herbert and Ian Storey, eds. The China Threat: Perception, Myths and Reality. New York: Routledge, 2002. 
Zhang, Weiwei. “The Allure of the Chinese Model.” Availability: <http://www.iht.com/ articles/2006/11/01/opinion/edafrica.php>.

"geguo canyu guoji zuzhi de bijiao" (Comparison of State Participation in International Organisations). Availability: <http://big5.china.com.cn/node_7000058/2007-04/02/ content_8047488.htm>, accessed July 8, 2011.

"kongzixueyuan: zhongguo wenhua yongbao shijie" (2011 Confucius Institute Asia Conference held in Korea). Availability: <http://cpc.people.com.cn/BIG5/n/2012/0810/c83083-18711779. html>, accessed August 10, 2012.

Submitted July 9, 2013 Accepted February 5, 2014

\begin{abstract}
Since the 1990s, alongside China's economic growth, the international community has fostered a general anxiety towards a "China threat." In order to relieve itself from suspicion, China adopted the dual strategies of "harmonious worldview" and "good neighbor policy." The strategies led to the use of soft power in China's foreign policy. China aimed to reduce security concerns implied by the threat theory by supporting an image that caters to international peace and development. This article seeks to explain how China achieves its interests in Southeast Asia through the use of soft power. The authors address the concepts of "harmonious worldview" and "good neighbor policy" and how the twin strategies and soft power have shaped China's foreign policy in recent years. This article aims to provide insights into China's policy options in Southeast Asia in the near future.
\end{abstract}

Keywords: China; Good Neighbor Policy; Harmonious Worldview; Soft Power; Southeast Asia.

\title{
Resumo
}

Desde os anos 1990, juntamente com o crescimento econômico da China, a comunidade internacional tem promovido uma ansiedade geral no sentido de uma "ameaça chinesa". Para aliviar-se da suspeita, a China adotou a dupla estratégia de "visão de mundo harmonioso" e "política de boa vizinhança". A estratégia levou ao uso do soft power na política externa da China. A China teve como objetivo reduzir as preocupações de segurança implícitos na teoria da ameaça, apoiando uma imagem que atende à paz e ao desenvolvimento internacional. Este artigo procura explicar como a China atinge os seus interesses no Sudeste da Ásia, por meio da utilização do soft power. Os autores abordam os conceitos de "visão de mundo harmonioso" e "política de boa vizinhança" e como ambas as estratégias juntamente com o soft power moldaram a política externa da China nos últimos anos. Este artigo tem como objetivo fornecer insights sobre as opções políticas da China no Sudeste Asiático em um futuro próximo.

Palavras-chave: China; política de boa vizinhança; visão do mundo harmoniosa; Soft Power; Sudeste Asiático. 